\title{
Programas de Optimización Perioperatoria, Enhanced Recovery y Fast-track: ¿Por qué están en auge? ¿Qué son realmente y cómo se implementan en la práctica? Perioperative optimization, enhanced recovery and fast-track programs: why are they booming? What are these programs actually and how are they implemented into practice?
}

\author{
Santiago Mc Loughlin ${ }^{1,2}$ (D) , Uriel Fraidenraij ${ }^{1,3}$ (D) , Adrián O. Álvarez ${ }^{1,4 * \text { (D) }}$
}

1. Servicio de Anestesiología, Hospital Italiano de Buenos Aires.

2. Director de la Red de Investigación Perioperatoria de América Latina (RIPAL). 3. Director de la Academia de Medicina Perioperatoria de América Latina (AMPAL). 4. Vice-President of Implementation Programs ERAS Society.

Presidente de ERAS

Latam.

Los autores declaran no tener conflictos de interés. Conflicts of interest None declared.

Correspondencia Correspondence: Santiago Mc Loughlin, E-mail: info@ academiaperioperatoria. com

\section{RESUMEN}

Desde 2015 a la fecha, los autores de esta revisión hemos implementado numerosos programas de optimización perioperatoria en Latinoamérica. En el siguiente artículo, presentamos una introducción general a los conceptos de optimización perioperatoria y resumimos nuestra experiencia trabajando en la región. También a lo largo de esta revisión, los lectores podrán encontrar desarrollados los tres elementos centrales de la optimización perioperatoria. En primer lugar, la constitución y los roles dentro un equipo perioperatorio. En segundo término, el registro sistemático y estandarizado de la práctica quirúrgica y sus resultados. Y, por último, la descripción del ciclo de mejoría continua como método de trabajo para ajustar la práctica diaria sobre la base del análisis de datos propios.

Palabras clave:ERAS, enhanced recovery, optimización perioperatoria, fast-track.

\section{ABSTRACT}

From 2015 to date, the authors of this review have implemented several enhanced recovery perioperative programs in Latin America. In the following article, we present a general introduction to the concepts of perioperative optimization and summarize our experience working in the region. Throughout this review, readers will also find the three fundamental elements of perioperative optimization. First, the creation and roles of a perioperative team. Second, the systematic and standardized registration of the surgical practice and its outcomes. And finally, the description of the continuous improvement cycle as a working method for adjusting daily practice based on the analysis of one's own data.

Keywords: ERAS, enhanced recovery after surgery, fast-track surgery
ID ORCID: Santiago Mc Loughlin, 0000-0003-1608-765X; Uriel Fraidenraij, 0000-0002-0267-7109; Adrián O.Álvarez, 0000-0001-8016-1135.

*Editor invitado del presente número. 
A diario y en forma creciente surgen publicaciones acerca de programas de optimización perioperatoria, recuperación acelerada o fast-track. Sin embargo, existe un uso heterogéneo de estos términos y en muchos casos queda poco claro cuál es, en efecto, la novedad de tales protocolos y cuál su verdadero impacto. El objetivo de la siguiente revisión introductoria a esta edición especial de la Revista es desarrollar por qué se produce el auge de dichos programas, cuál es su definición, cómo los implementamos en la práctica y cuáles han sido los resultados de su implementación.

¿Por qué el auge de los protocolos de optimización perioperatoria?

La idea de alcanzar una mejor recuperación posoperatoria, con menos complicaciones y para el mayor número de pacientes posible, ha sido siempre el objetivo de todo equipo quirúrgico. Sin embargo, en las últimas décadas, este objetivo se ha transformado en una necesidad de todo el sistema de salud.

El crecimiento poblacional y del volumen de cirugías ha superado ampliamente el de la infraestructura hospitalaria dando lugar a una escasez mundial de camas de internación ${ }^{1-5}$. Por otro lado, el cambio en la modalidad de pago de los servicios quirúrgicos "fee-forservice" (aumentan los ingresos cuantas más prestaciones se utilicen) hacia el denominado "pay-for-performance" (pago por módulo), genera presión por parte de los financiadores para realizar una práctica médica sustentable ${ }^{6}$. Es en este contexto donde se produce el auge de los programas de optimización perioperatoria a nivel mundial. Estos programas proponen la solución al objetivo de los equipos quirúrgicos de estandarizar el cuidado y aumentar el volumen de pacientes tratados. Al mismo tiempo, atienden la necesidad del sistema de salud de ofrecer una recuperación de calidad, a través de una práctica segura y con la competitividad necesaria para hacerla sustentable en el tiempo ${ }^{7}$.

\section{Fast-track, enhanced recovery, ERAS ${ }^{\circledR}$ y optimización} perioperatoria. ¿Quién es quién?

Existe por momentos confusión acerca de los tipos de programas de cuidados perioperatorios, sus métodos y sus objetivos. Los términos fast-track, recuperación acelerada, medicina perioperatoria y $\mathrm{ERAS}^{\circledR}$ se utilizan a menudo como sinónimos intercambiables. Esta variedad en la nomenclatura responde a una evolución histórica del término y a las distintas sociedades o grupos de estudio que han surgido alrededor de este nuevo paradigma. A fines de la década del 90, el Profesor Kehlet, de Dinamarca, publica uno de los primeros artículos revisando los principales factores asociados con la rehabilitación posoperatoria (dolor, disfunción gastrointestinal, hipoxemia e inmovilización) y la in- fluencia de los cuidados tradicionales sobre estos factores (uso rutinario de sonda nasogástrica, drenajes, restricción a la ingesta posoperatoria) ${ }^{8}$. Apenas algunos años más tarde, el mismo autor comunica en el British Medical Journal los resultados del manejo perioperatorio bajo una nueva modalidad de cuidado a la que denomina "fast-track surgery" . Esta nueva modalidad de cuidado empieza a tomar fuerza en distintos equipos quirúrgicos que rápidamente perciben que el objetivo propuesto por Kehlet no es el alta rápida o acelerada del paciente sino su recuperación mejorada (enhanced). Sin duda, una mejor recuperación conduce a una disminución de la estadía hospitalaria, pero el objetivo principal es la calidad y seguridad de atención del cuidado perioperatorio y no su velocidad ${ }^{8}$. De esta forma, el término "fast-track" comienza a ser reemplazado en distintas publicaciones por "enhaced recovery".

También a inicios del milenio, distintos equipos quirúrgicos, principalmente escandinavos e ingleses liderados por el Profesor Ljungqvist, comienzan a nuclearse en grupos de estudio que promueven la revisión del cuidado tradicional y el abordaje multimodal e integral del paciente quirúrgico. Estos grupos continúan trabajando en conjunto y se constituyen formalmente como la Enhanced Recovery After Surgery (ERAS ${ }^{\circledR}$ ) Society en el año 2010. Esta sociedad desarrolla sus propios protocolos y programas de entrenamiento, que son posteriormente implementados bajo supervisión y capacitación por parte de miembros de la sociedad. A partir de entonces se denomina a los programas quirúrgicos certificados por la sociedad científica como equipos o programas ERAS ${ }^{\circledR}$. Con el correr del tiempo, distintas sociedades a nivel mundial, como por ejemplo ASER en los Estados Unidos o SMaRT en Canadá, surgen con el mismo objetivo de promover la optimización perioperatoria.

Dentro de Argentina, existen equipos quirúrgicos pioneros en la utilización de las guías de recuperación optimizada. En la Revista Argentina de Cirugía, hemos podido conocer las experiencias del Dr. Nari y cols. en resecciones hepáticas y la del equipo del Hospital Británico en cirugía colorrectal ${ }^{10-12}$. Sin embargo, ya sea dentro de un programa de la sociedad ERAS ${ }^{\circledR}$, Enchanced Recovery o un protocolo denominado fast-track, la característica distintiva de un programa orientado a la optimización perioperatoria no es el contenido técnico específico de sus guías clínicas sino la aplicación de un sistema de trabajo. Este sistema de trabajo consta de tres elementos fundamentales:

1. La formación de un equipo multidisciplinario.

2. El registro sistemático del cuidado y los resultados perioperatorios.

3. La implementación de un ciclo de mejoría continúa por parte del equipo utilizando los datos.

Este ciclo de mejoría continua está basado en cuatro elementos que se utilizan a la hora de abordar cualquier problema o cambio deseado: a) analizar los datos para un diagnóstico de situación, b) planificar una intervención, c) actuar y d) auditar su efecto ${ }^{7}$. 


\section{Implementación de los protocolos}

Todos los programas de optimización perioperatoria comienzan con la formación de un equipo multidisciplinario de trabajo que tiene como objetivo fijar reuniones semanales donde analizará la situación y planificará las acciones. Estas reuniones semanales con representantes de distintas áreas (anestesia, cirugía, enfermería, nutrición, etc.) son clave para abordar las diferentes etapas de la atención quirúrgica como un proceso indivisible. El equipo consta de un líder médico de proyecto, habitualmente un cirujano o anestesiólogo, cuya función es asumir la responsabilidad médica del programa ante los pacientes y autoridades, fijar los objetivos del equipo y gestionar los recursos necesarios. Un coordinador del programa fija las reuniones, facilita la interacción de los servicios y tiene un papel clave en unificar las etapas (prequirúrgica, intraoperatoria y posquirúrgica) y especialidades (nutricionistas, kinesiólogos, etc.) del cuidado perioperatorio de cada paciente. Finalmente, un integrante del equipo está dedicado a la recolección sistemática de los datos perioperatorios de cada paciente en el sistema de auditoría continua.

En el caso de los programas implementados a través de la sociedad ERAS ${ }^{\circledR}$, los integrantes del equipo multidisciplinario realizarán una etapa de capacitación que consta de 4 seminarios separados por 3 períodos de acción junto a instructores de ERAS ${ }^{\circledR}$ Society. El primer seminario consta de una introducción a los elementos principales de las guías de ERAS ${ }^{\circledR}$ Society y capacitación en el uso de la base de datos. El período de acción que sigue a este primer seminario es la recolección de datos de los primeros 50 casos de cirugía programada, consecutivos y no seleccionados luego del primer seminario. Este período de registro se denomina Pre-ERAS. Durante dicho período, el equipo multidisciplinario continúa con su práctica habitual sin realizar ningún cambio de conducta, pero recolectando toda la información de los pacientes en la base de datos de ERAS $^{\circledR}$ Society. Este grupo de pacientes (Pre-ERAS) serán considerados la muestra basal. En el segundo seminario, el equipo bajo entrenamiento se dedica fundamentalmente a revisar los resultados de la muestra basal de pacientes junto a los instructores. Durante la revisión de dichos pacientes, en muchas oportunidades, se constatan grandes diferencias entre lo que equipo quirúrgico supone que realiza en cada paciente y lo que efectivamente ocurre. Este fenómeno no es exclusivo de nuestra región: un estudio reciente realizado en los Estados Unidos demostró que los pacientes reciben en promedio solo el $55 \%$ de las pautas que los centros médicos refieren utilizar en forma cotidiana ${ }^{13}$.

Utilizando los datos recolectados por el equipo (datos Pre-ERAS) se define en conjunto un objetivo (p. ej., aumentar la adherencia a los elementos de las guías, o reducir el tiempo de internación) y el método para alcanzarlo. Comienza así el segundo período de acción: el equipo trabaja para incrementar la adherencia a la práctica que habían fijado previamente como objetivo y continúa registrando de forma sistemática a estos primeros pacientes de la fase ERAS (habitualmente 10 pacientes). Como es de esperar, el tercer seminario se dedica a revisar, en forma conjunta equipo en entrenamiento y equipo de instructores, estos nuevos diez pacientes, la adherencia a los objetivos planteados y determinar cuáles serán los nuevos objetivos que alcanzar. Nuevamente comienza un período de acción durante el cual el equipo en entrenamiento recolecta los datos de los pacientes hasta llegar a aproximadamente 50 casos, así se arriba al cuarto seminario. En este se revisan y comparan los pacientes de la fase ERAS vs. la Pre-ERAS (50 versus 50 ). Se revisa el cambio en la práctica diaria respecto de los objetivos que el equipo se había planteado y se analiza la adherencia global a las recomendaciones (guías ERAS) específicas para el tipo de procedimiento quirúrgico abordado. Si la adherencia global a las recomendaciones clínicas es mayor del $70 \%$ o si se duplicó la adherencia de la muestra Pre-ERAS comparada con los pacientes ERAS, la capacitación se considera completa, esa nueva unidad se certifica como equipo ERAS y, además, se publica en la web de RAAS $^{\circledR}$ Society.

\section{Un sistema de gestión de datos unificado}

Como se mencionó anteriormente, la capacidad de contar con datos fiables es indispensable y distintiva de los programas de optimización perioperatoria. Sin datos, es imposible tener un diagnóstico de situación, e imposible detectar y corregir errores en los procesos. Sin embargo, con el cuidado quirúrgico tradicional en nuestra región (y también en otras latitudes), la información a menudo es recolectada deficitariamente por los gobiernos o grandes instituciones, lo que da como resultado políticas de salud ineficaces que generan gran derroche de dinero, tiempo y energía. En nuestro país, los dos tipos de auditorías más frecuentes son la auditoría contable y la auditoría realizada por parte de los profesionales médicos cuando realizan un análisis (habitualmente retrospectivo) de sus resultados con fines de difusión científica. Este segundo tipo de auditoría aporta datos que pueden contribuir a nuestro conocimiento y atención de los pacientes, pero habitualmente no se realiza de forma sistemática como parte de un sistema de trabajo, consumiendo tiempo y esfuerzo para cada nuevo interrogante planteado.

En el caso de muchos programas de la sociedad ERAS $^{\circledR}$, la recopilación de los datos del cuidado perioperatorio se efectúa a través de un software comercial en línea llamado ERAS Interactive Audit System $\left(\right.$ EIAS) ${ }^{\circledast}$ (Fig. 1). En esta plataforma, cada equipo quirúrgico registra sistemáticamente los datos de cada uno de sus pacientes. La recolección electrónica de datos utilizando EIAS evita problemas comunes, como la falta de 
registros médicos claros, y provee un almacenamiento electrónico que requiere únicamente el acceso a Internet. Para cada grupo de cirugías (p. ej., colon/recto, hígado/vía biliar, cabeza y cuello), el número de variables y su definición es igual en todos los centros del mundo. En otras palabras, es la misma base de datos para cualquier hospital del mundo y todos registran de la misma forma. Esto permite hacer semana a semana un diagnóstico de situación y auditoría comparada en el tiempo y comparada con cualquier otro hospital o equipo (Fig. 2). Por otro lado, durante este año comienza la implementación en Latinoamérica de una herramienta mobile para el registro de datos perioperatorios. Esta aplicación, denominada My Journey ${ }^{\circledR}$, adaptada a la realidad de nuestra región, facilita el registro de datos, la educación del paciente y brinda además un sistema de alerta temprana ante eventos (Fig. 3).

Independientemente del tipo de software comercial utilizado, el registro sistemático y estandarizado es condición sine qua non para guiar la práctica asistencial y potenciar la investigación por parte de los equipos quirúrgicos que deseen implementar un programa de optimización perioperatoria.

Los resultados de los programas de optimización perioperatoria a nivel mundial y en América Latina

Los programas de optimización perioperatoria iniciaron su desarrollo en cirugía colorrectal y el grueso de la experiencia se basa en este grupo de cirugías. Distintas publicaciones han demostrado consistentemente una reducción de la estadía hospitalaria en pacientes so- metidos a cirugía colorrectal bajo los programas ERAS 14-16 Estos resultados han sido observados tanto en cirugía abierta como laparoscópica ${ }^{17}$, en la estadía en piso y en áreas cerradas ${ }^{18}$ e incluso en pacientes con alta carga de morbimortalidad ${ }^{19}$. Existe fuerte evidencia que indica que, a mayor adherencia porcentual a las recomendaciones de los programas, mayor es la reducción de la estadía hospitalaria ${ }^{14,16}$. Del mismo modo, una mayor adherencia a las recomendaciones ha demostrado un impacto positivo sobre las complicaciones posoperatorias y los costos de atención ${ }^{20-22}$. Estos resultados positivos en el ámbito de la cirugía colorrectal han fomentado la aplicación de los programas de recuperación acelerada a otras áreas de la cirugía general e incluso otras especialidades quirúrgicas. Se han observado resultados positivos sobre la estadía hospitalaria y las complicaciones posoperatorias en cirugía de tórax ${ }^{23}$, gastrectomías $^{24}$ y resecciones hepáticas ${ }^{25}$. Del mismo modo, los resultados en cirugía ortopédica ${ }^{26}$, urología ${ }^{27}$ y ginecooncología ${ }^{28}$ son alentadores y demuestran beneficios atribuibles a la aplicación de programas diseñados específicamente para cada especialidad o tipo de cirugía.

Afortunadamente, los protocolos de optimización perioperatoria se expandieron y continúan haciéndolo en distintas especialidades y hospitales de nuestro continente. El punto de partida de ERAS ${ }^{\circledR}$ en América Latina fue el programa de implementación liderado por Robin Kennedy, Olle Ljungqvist y Jennifer Burch para el Hospital Italiano de Buenos Aires, República Argentina. Esto derivó en el primer centro de excelencia ERAS ${ }^{\circledR}$ de la región en 2015. También en el año 2015 se sumaron a esta iniciativa un equipo de Bogotá (Clínica Reina Sofía Org Sanitas) y otro de México (Hospital Civil de Guada-

\section{口 FIGURA 1

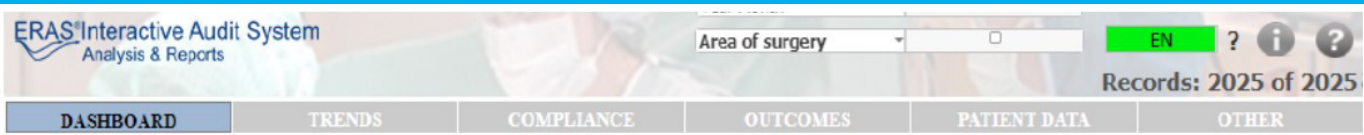

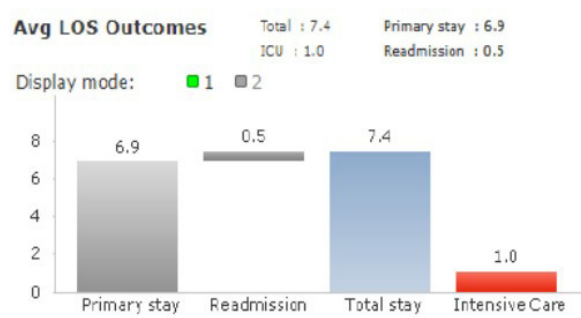

Complications (Primary and Flw-up)

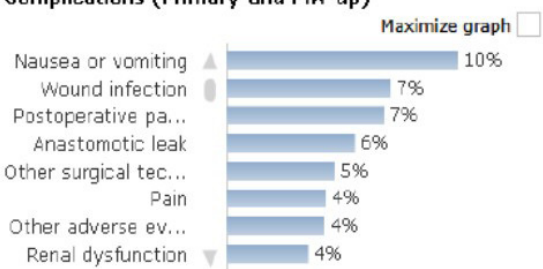

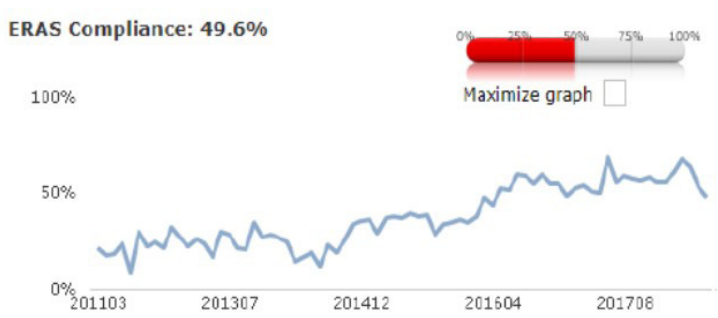

Number of Operations

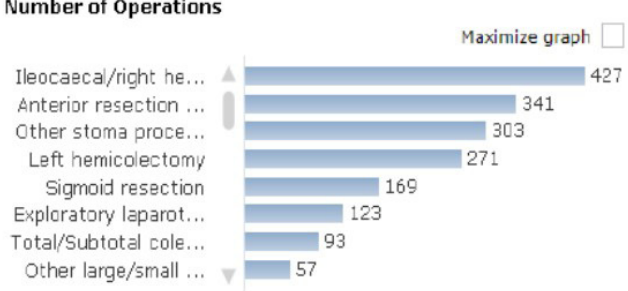

Pizarra inicial de trabajo del sistema de gestión de datos EIAS. Puede observarse un resumen de rápida visualización de distintas variables del equipo analizado. (Avg LOS outcome: Estadía hospitalaria promedio; ERAS compliance: Adherencia \% a los cuidados recomendados por la guía). 


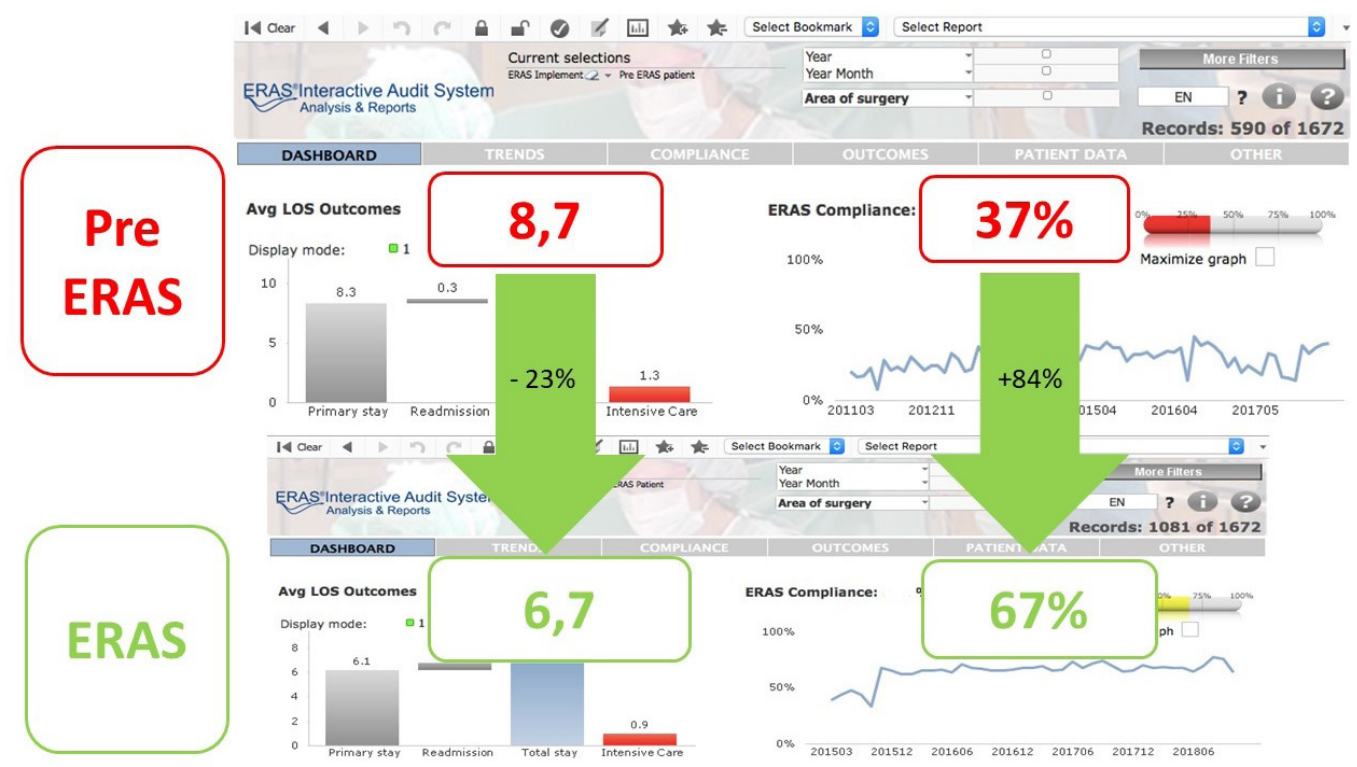

Datos comparados de los centros de Latinoamérica que integran los programas ERAS. En la parte superior pueden observarse los resultados de 590 pacientes previos a la implementación del programa ERAS con una estadía promedio de 8,7 noches y una adherencia a las recomendaciones del $37 \%$. En la parte inferior se observan los datos de 1081 pacientes incluidos en los programas ERAS con una estadía promedio de 6,7 noches y $67 \%$ de adherencia a las recomendaciones. Período incluido $2015-2018$.

lajara), ambos hoy en día centros de excelencia acreditados por la sociedad ERAS ${ }^{\circledR}$. En 2016, dos instituciones uruguayas (CAMOC de Carmelo y la Médica Uruguaya Corporación de Asistencia Médica, de Montevideo) se unieron a los esfuerzos por mejorar la atención perioperatoria en la región y se encuentran actualmente acreditados como centros de excelencia. Del mismo modo, en 2016, dos grandes centros médicos brasileños y referentes regionales iniciaron sus programas de implementación en Brasil (Hospital Israelita Albert Einstein de San Pablo y Santa Casa de la Misericordia de Porto Alegre). En 2018 y 2019, la Clínica Alemana de Santiago de Chile y el Instituto Nacional de Cancerología de México también se sumaron a la iniciativa. Al igual que en la experiencia mundial, la implementación y adherencia a los protocolos de optimización perioperatoria ha demostrado en la región una reducción de las complicaciones posoperatorias y la estadía hospitalaria ${ }^{29,30}$. Durante este año, 8 nuevos hospitales finalizarán en Brasil su programa de implementación ERAS ${ }^{\circledR}$ y hemos comenzado con el entrenamiento del Hospital Universitari Vall d'Hebron a través del programa de implementación online de ERAS LatAm.

\section{Conclusiones}

Los programas de optimización perioperatoria representan un cambio de paradigma en los cuidados quirúrgicos. Cada programa ofrece recomendaciones técnicas específicas para los distintos tipos de cirugías basadas en evidencia científica recopiladas en guías de manejo clínico.

\section{- FIGURA 3}

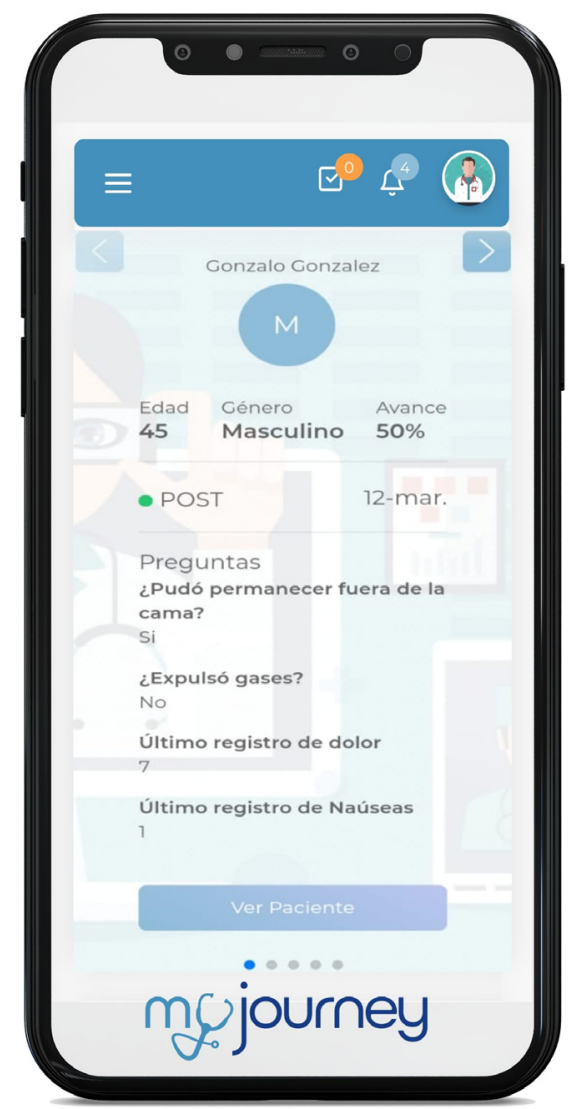

Pizarra de My Journey en versión mobile presentando resumen de un paciente que cursa su internación durante el posoperatorio. 
Sin embargo, las guías por sí solas no alcanzan para generar el cambio necesario para mejorar los resultados. Los elementos comunes a todos los programas y fundamentales para alcanzar el éxito son:

- la formación de un equipo multidisciplinario

- el registro sistemático y estandarizado de cada caso y la auditoría continua de resultados y la adherencia a los procesos de cuidado

- la implementación de un ciclo de mejoría continua - (analizar, planificar, actuar y auditar)

La aplicación de los programas de optimización perioperatoria ha derivado en una reducción de las complicaciones, de la estadía hospitalaria y un ahorro en los costos de atención. Estos beneficios han sido observados en múltiples áreas de la cirugía general e incluso en otras especialidades quirúrgicas. En el contexto actual de escasez de camas y cambios en los sistemas de pagos, estos programas continuarán recibiendo una creciente atención y financiamiento por parte de distintos agentes y sistemas de salud. Este contexto abre una oportunidad para que podamos mejorar nuestra práctica diaria y nuestro desarrollo en investigación tanto en volumen como en calidad.
Every day, the number of publications about perioperative optimization, enhanced recovery or fast-track programs for increases. However, the use of these terms is not uniform, and in many cases the innovations of these protocols and their actual impact remain unclear. The aim of this introductory review to this special issue of the Revista is to develop the reasons for the boom of these programs, define them, describe how they are implemented into practice and the results of such implementation.

Why are perioperative optimization protocols booming?

The idea of achieving a better postoperative recovery, with fewer complications and for as many patients as possible, has always been the goal of every surgical team. However, in recent decades, this goal has become a need for the entire healthcare system.

Population growth and the increased volume of surgeries have far surpassed hospital infrastructure resulting in shortage of hospital beds worldwide ${ }^{1-5}$. Furthermore, the shift from fee-for-service payment model (revenues increase when more services are provided) for surgical services to pay-for-performance (payment per module) makes payers exert pressure for a sustainable medical practice ${ }^{6}$. In this setting, perioperative optimization programs are booming worldwide. These programs propose a solution to standardize surgical care and increase the volume of patients treated, and at the same time, they address the healthcare system need to offer high quality recovery, through a safe practice and with the necessary competitiveness to ensure sustainability over time ${ }^{7}$.

Fast-track, enhanced recovery, ERAS ${ }^{\circledR}$ and perioperative optimization. Who is who?

There is much confusion about the types of perioperative care programs, their methods and their goals. The terms fast-track, enhanced recovery, perioperative medicine and ERAS $^{\circledR}$ programs are often used as interchangeable synonyms. This diverse terminology responds to a historical evolution of the term and to the different societies or study groups that have emerged around this new paradigm. By the end of the nineties, Professor Kehlet, from Denmark, published one of the first articles reviewing the main factors associated with postoperative rehabilitation (pain, gastrointestinal dysfunction, hypoxemia and immobilization) and the influence of traditional care on these factors (routine use of nasogastric tube, drains, restriction on oral intake after surgery $)^{8}$. Just a few years later, the same author reported in the British Medical Journal the results of perioperative management under a new model of care which he called fast-track surgery ${ }^{9}$. This new model of care became stronger in different surgical teams, which quickly understood that the goal proposed by Kehlet was not the rapid or accelerated discharge of patients, but their enhanced recovery. Undoubtedly, enhanced recovery results in shorter length of hospital stay, but the main target is the quality and safety of perioperative care rather than the speed of discharge ${ }^{8}$. In this way, the term fast-track began to be replaced by enhanced recovery in different publications.

Also, at the beginning of the millennium different surgical teams, mainly from Scandinavia and the United Kingdom, led by Professor Ljungqvist, began to gather in study groups that promoted the review of traditional care and the multimodal and comprehensive approach to the surgical patient. These groups continue working together and formally constituted as the Enhanced Recovery After Surgery (ERAS ${ }^{\circledR}$ ) Society in 2010. This society develops its own protocols and training programs, which are then implemented under the supervision and training of the members of the society. Since then, the surgical programs certified by the scientific society have been referred to as ERAS $^{\circledR}$ teams or programs. Over time, different societies worldwide, as ASER in the United States or SMaRT in 
Canada, have emerged with the same goal of promoting perioperative optimization.

In Argentina, there have been pioneer surgical teams in the use of optimized recovery guides. From previous publications of Revista Argentina de Cirugía, we have been able to learn about the experiences of Dr. Nari et al. in liver resections and that of the Hospital Británico team in colorectal surgery ${ }^{10-12}$. However, whether as part of an ERAS $^{\circledR}$ program, Enhanced Recovery or fast-track protocols, the distinctive feature of a program aimed at perioperative optimization is not the specific technical content of its clinical guidelines, but the application of a working system with three fundamental elements:

1. The creation of a multidisciplinary team.

2. Systematic registration of perioperative care and outcomes.

3. Implementation of a continuous improvement cycle by the team using the data.

This cycle of continuous improvement is based on four elements that are used when addressing any problem or desired change: a) analyze data to make a diagnosis of the situation, b) plan an intervention, c) act on the plan made, and d) audit the effect?

\section{Implementation of protocols}

The implementation of all the enhanced recovery programs begins with the creation of a multidisciplinary team with the aim of setting up weekly meetings to analyze the situation and plan the actions. These weekly meetings with members of different areas (anesthesiologists, surgeons, nurses, and nutritionists, among others) are key to addressing the different stages of surgical care as an indivisible process. The medical leader is usually a surgeon or an anesthesiologist, who holds the medical responsibility for the program to patients and authorities, sets the goals of the team, and manages the resources needed. The program coordinator schedules meetings, facilitates interaction between units and plays a key role in coordinating the stages (preoperative, intraoperative and postoperative care) and specialists (nutritionists, kinesiologists, among others) for the perioperative care for each patient. Finally, a member of the team is dedicated to collect systematically each patient data for continuous auditing.

In the case of the programs implemented through the ERAS ${ }^{\circledast}$ Society, the members will undergo a training phase which consists of four seminars separated by three active working periods with instructors from the ERAS ${ }^{\circledR}$ Society. The first seminar consists of an introduction to the main elements of the ERAS ${ }^{\circledR}$ Society guidelines and training in data entry. The period of action that follows this first seminar is the collection of data from the first 50 consecutive unselected cases of scheduled surgery after the first seminar. During this registration period, known as preERAS stage, the multidisciplinary team continues with its routine care without changes, but all the information from these patients is entered into the ERAS ${ }^{\circledR}$ Society database. This group of Pre-ERAS patients is considered the baseline sample. The second seminar is mainly dedicated to reviewing the results of this baseline sample of patients with the instructors. The review of these patients in many cases shows a great discrepancy between what the surgical team believes that their common practice is and what actually happens. This phenomenon is not confined to our region: a recent study conducted in the United States showed that, on average, patients received only $55 \%$ of the guidelines recommendations that are allegedly followed by the medical centers ${ }^{13}$.

On the basis of the data collected (Pre-ERAS data), the team defines a target (e.g., to increase adherence to the elements of the guidelines or to reduce length of hospital stay) and how to achieve it. The second active working period then starts: the team works to increase the adherence to the practice that they had previously set as their objective and continues to systematically record these first ERAS patients (usually 10 patients). As expected, during the third seminar the team of trainees and the team of instructors will jointly review these 10 new patients, the adherence to the objectives set, and determine what new objectives will be achieved. Again, an active working period of the team begins during which patient data is collected to reach approximately consecutive 50 cases, thus reaching the fourth seminar. In this seminar the patients of the ERAS phase are reviewed and compared with the Pre-ERAS patients ( 50 vs. 50 ). The change in daily practice that the team had set is reviewed and the global adherence to the recommendations in the specific ERAS guidelines corresponding to the type of surgery is analyzed. If the overall compliance is greater than $70 \%$ or if the compliance doubles the Pre-ERAS sample, the training is considered complete, and that new unit is certified as ERAS team and published in the ERAS ${ }^{\circledR}$ Society website.

\section{A unified database management system}

As mentioned above, the ability to have reliable data is indispensable and distinctive of perioperative optimization programs. It is impossible to make a diagnosis of the situation and to detect and correct errors in the processes without data. However, with standard surgical care in our region (and in other locations), the information is often insufficiently collected by governments or large institutions, resulting in ineffective health policies that are a waste of money, time and energy. In our country, the two most common types of audits are the financial statement audit and the one carried out by physicians when they perform an analysis (usually retrospective) 
of their results for scientific dissemination. This second type of audit provides information that can contribute to our knowledge and to the care of patients but is not systematically performed as part of a method of work, consuming time and effort for each new question raised.

In many ERAS $^{\circledast}$ Society programs, data collection of perioperative care is achieved through the ERAS Interactive Audit System (EIAS) an on-line, web based interactive software tool (Fig. 1). In this platform, each surgical team systematically reports records the data of each of its patients. Electronic data collection through EIAS avoids common problems as the lack of clear medical records and provides electronic storage that requires only access to the Internet. For each group of surgeries (e.g., colorectal, liver/biliary tract, or head and neck), the number of variables and definitions are the same in all centers worldwide. In other words, EIAS is the same database for any hospital worldwide and the information is recorded in the same way. This allows for a weekly diagnosis of the situation and auditing compared over time and with any other hospital or group of the ERAS ${ }^{\circledR}$ society (Fig. 2). During this year, a mobile tool for recording perioperative data will be implemented in Latin America. This application, called My Journey ${ }^{\circledR}$, is adapted to the reality of our region and facilitates data recording and patient education and provides an early warning system in case events occur (Fig. 3).

Regardless of the type of commercial software used, systematic and standardized recording is a sine qua non condition to guide care and enhance research by surgical teams wishing to implement a perioperative optimization program.

Results of perioperative optimization programs worldwide and in Latin America

Perioperative optimization programs were first developed for colorectal surgery and most of the experience is based on this type of surgeries. Different publications have consistently demonstrated a reduction in length of hospital stay in patients undergoing colorectal surgery following the ERAS programs ${ }^{14-16}$. These results have been observed in open surgery as well as in laparoscopic procedures ${ }^{17}$, in patients hospitalized in general wards or critical care units ${ }^{18}$ and even in high-risk patients ${ }^{19}$. There is strong evidence indicating greater reduction in length of hospital stay when the compliance with ERAS $^{\circledR}$ guidelines is greater ${ }^{14,16}$. Similarly, the higher adherence to $E R A S^{\circledR}$ guidelines has demonstrated a positive impact on postoperative complications and costs of care $\mathrm{c}^{20-22}$. These positive outcomes in colorectal surgery have encouraged the implementation of fast-track recovery programs in other areas of general surgery and even other surgical specialties. Positive results have been observed in length of hospital stay and postoperative complications in thoracic surgery ${ }^{23}$, gastrectomies ${ }^{24}$ and liver resections ${ }^{25}$. In the same sense, the results in orthopedic ${ }^{26}$, urology ${ }^{27}$ and gynecologic oncology surgery ${ }^{28}$ are encouraging and demonstrate benefits attributable to the implementation of programs specifically designed to each specialty or type of surgery.

\section{- FIGURE 1}

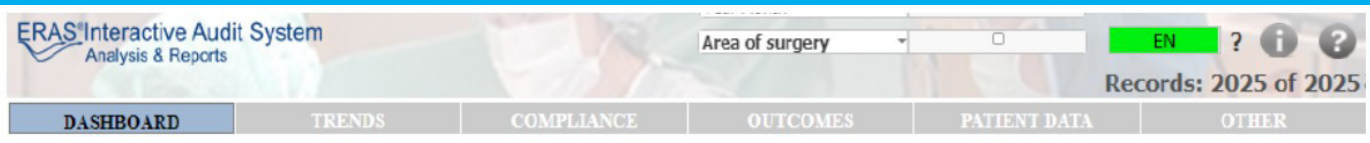

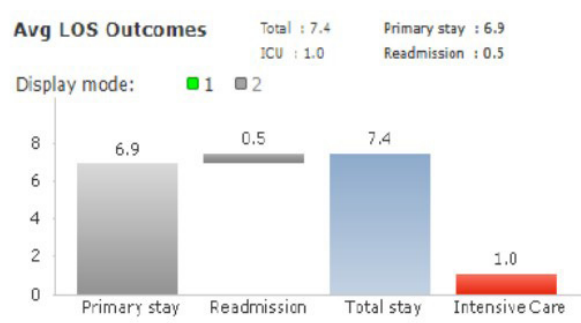

Complications (Primary and Flw-up)

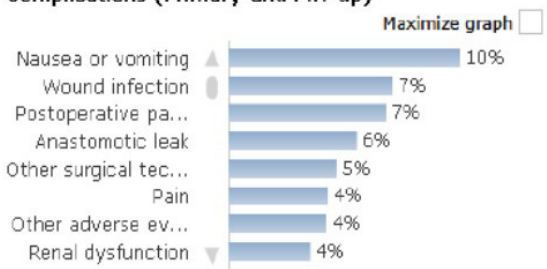

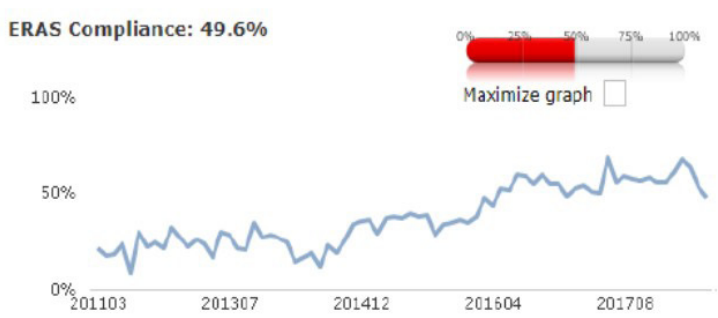

Number of Operations

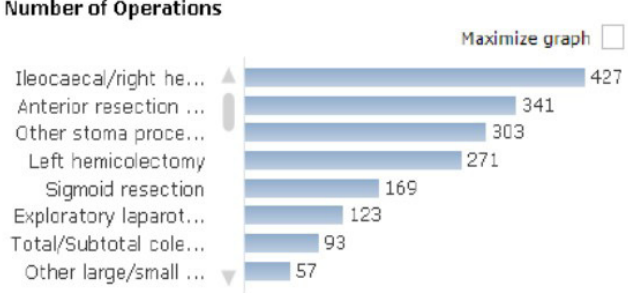




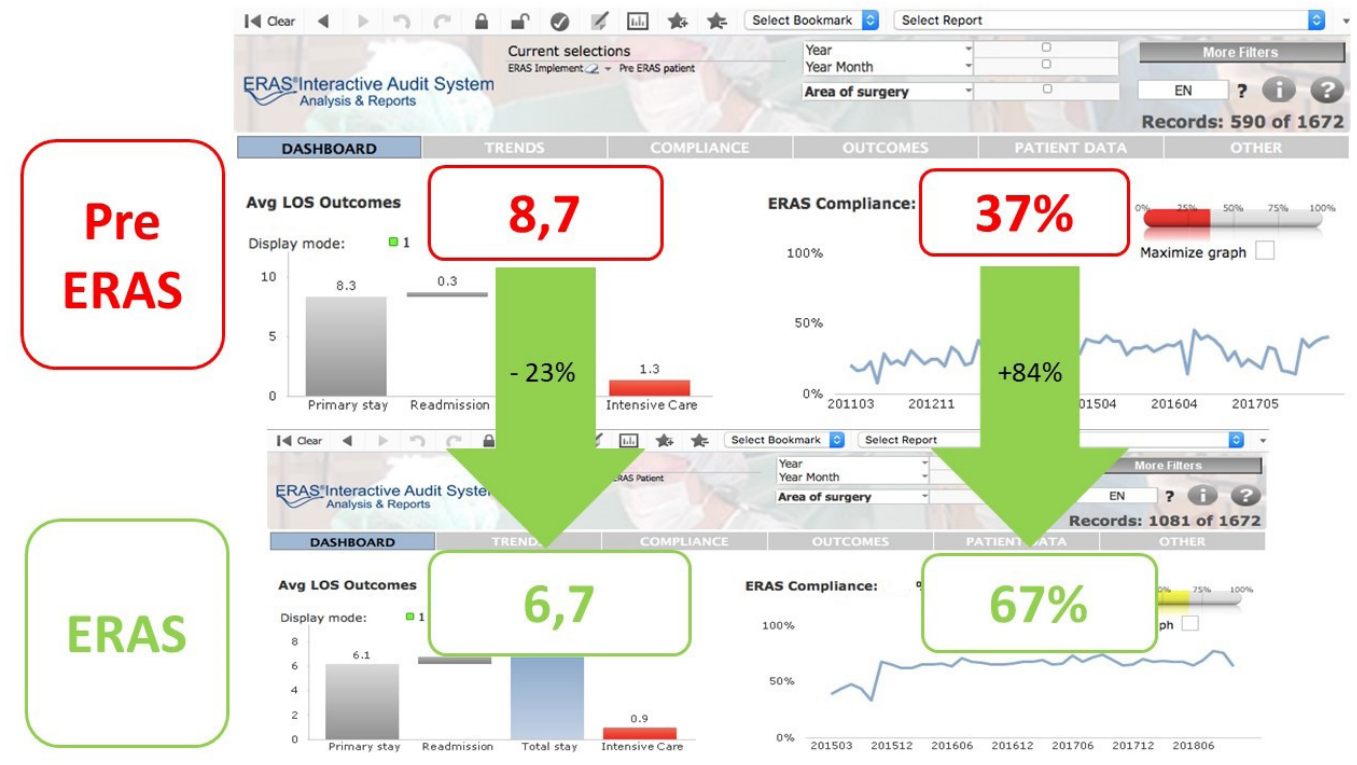

Comparative data of the Latin American ERAS programs. Above: results of 590 patients before the implementation of the ERAS program with an average length of hospital stay of 8.7 nights and an adherence to recommendations of $37 \%$. Below: data from 1081 patients included in the ERAS programs with an average length of hospital stay of 6.7 nights and adherence to the recommendations of $67 \%$. Period included $2015-2018$.

Fortunately, the perioperative optimization protocols have expanded over time in different specialties and hospitals across our continent. The starting point for ERAS $^{\circledR}$ in Latin America was the implementation program led by Robin Kennedy, Olle Ljungqvist and Jennifer Burch in Hospital Italiano de Buenos Aires, Argentina. This led to the development of the first ERAS ${ }^{\circledR}$ center of excellence in the region in 2015. In the same year, a team from Bogotá (Clínica Reina Sofía Org Sanitas) and another from Mexico (Hospital Civil de Guadalajara) joined this initiative, and today both are centers of excellence accredited by the ERAS $^{\circledR}$ society. In 2016, two institutions in Uruguay (CAMOC in Carmelo and Médica Uruguaya Corporación de Asistencia Médica, in Montevideo) also joined the efforts to improve perioperative care in the region and are currently accredited as centers of excellence. Similarly, in 2016, two large medical centers in Brazil, which are regional benchmarks, started the implementation of their programs (Hospital Israelita Albert Einstein in São Paulo and Santa Casa de la Misericórdia in Porto Alegre). In 2018 and 2019, Clínica Alemana in Santiago de Chile and Instituto Nacional de Cancerología in México also joined the initiative. Like the worldwide experience, the implementation of and adherence to perioperative optimization protocols have demonstrated a reduction in postoperative complications and length of hospital stayin the region ${ }^{29,30}$. During this year, 8 new hospitals in Brazil will complete their ERAS $^{\circledR}$ implementation program and we have started training at Hospital Universitari Vall d'Hebron through the ERAS LatAm online implementation program.

\section{— FIGURE 3}

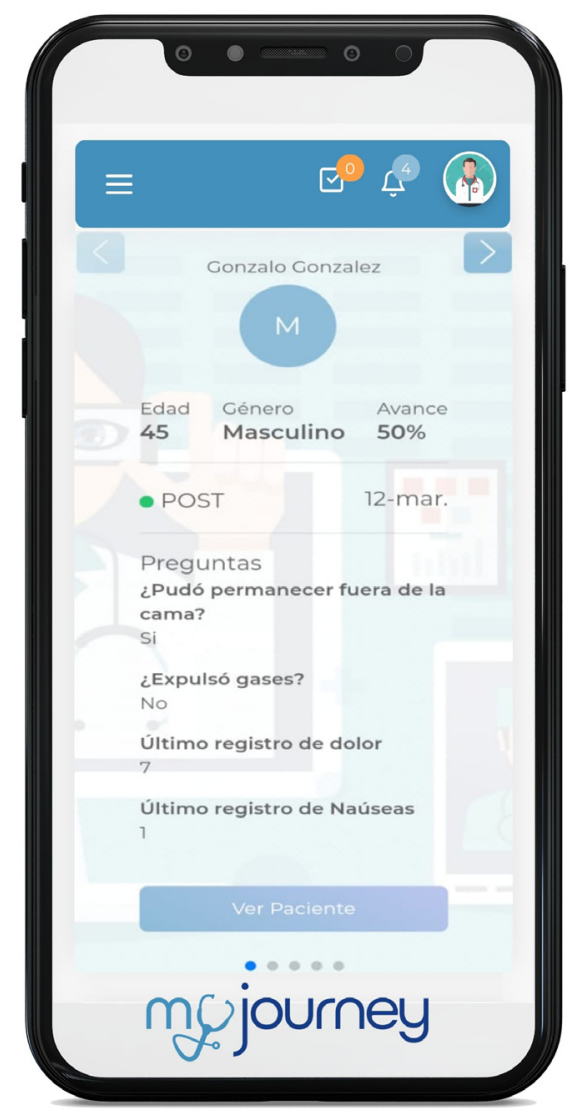

Dashboard of the mobile version of My Journey with a summary of a patient's postoperative record. 


\section{Conclusions}

Perioperative optimization programs represent a paradigm shift in perioperative care. Each program offers evidence-based technical recommendations compiled in clinical management guidelines that are specific for the different types of surgery.

However, the guidelines alone are not enough to bring about the change needed to improve results. The key elements which are common to all the programs and fundamental to reach success are:

- the creation of a multidisciplinary team

- systematic and standardized registration of each case and continuous auditing of compliance using the EIAS database

- implementation of a continuous improvement cycle (analyze, plan, act and audit)

The implementation of perioperative optimization programs has led to a reduction in complications, length of hospital stay and savings in care costs. These benefits have been observed in multiple areas of general surgery and even in other surgical specialties. In the current context of beds shortage and changes in payment systems, these programs will continue to receive increasing attention and funding from different health care agents and systems. This context opens an opportunity to improve our daily practice and our performance in the volume and quality of research.
1. NHS. Admissions and Bed management in NHS acute [Internet]. 2000. Available from: https://www.nao.org.uk/report/inpatientadmissions-and-bed-management-in-nhs-acute-hospitals.

2. OECD (2019), Hospital beds (indicator). (Accessed on $30 \mathrm{Oct}$ ). 2018.

3. Israel Ministry of Health. Inpatient Institutions and Day Hospital Units in Israel. 2011.

4. Weiser TG, Haynes AB, Molina G, Lipsitz SR, Esquivel MM, Uribeleitz T, et al. Surgical Services : Access and Coverage Estimate of the global volume of surgery in 2012: an assessment supporting improved health outcomes. Lancet. 2012;385(Suppl2):94305.

5. Meara JG, Leather AJ, Hagander L, Alkire BC, Alonso N, Ameh EA, et al. Global Surgery 2030: evidence and solutions for achieving health, welfare, and economic development. Lancet. 386(9993):569-624.

6. Hale D. Pay for Performance - Are You Prepared ? Female Pelvic Med Reconstr Surg. 2019;22(3):2015-7.

7. Ljungqvist O, Scott M FK. Enhanced Recovery After Surgery A Review. Jama Surg. 2017;152(3):292-8.

8. Kehlet $\mathrm{H}$. Multimodal approach to control postoperative pathophysiology and rehabilitation. Br J Anaesth. 1997;78(5):60617.

9. Wilmore DW, Kehlet H. Clinical review: Recent advances: Management of patients in fast track surgery. BMJ. 2001;322:473-6.

10. Nari G, Layun J, Mariot D, Viotto L, De Elias ME, López F, y col. Resultados de la aplicación de un programa Enhanced Recovery (ERP) en resecciones hepáticas abiertas. Rev argent cir. 2019;111(4):227-35.

11. Patron Uriburu J, Tanoni B, Ruiz H, Cillo M, Tyrrell C, Salomón M. Protocolo ERAS enCirugía colónica laparoscópica: evaluación de una serie inicial. Rev Argent Cirug. 2015;107(2):63-71.

12. Nari GA, Molina L, Gil F, Vioto L, Layún J, Mariot D, y col. Enhanced Recovery Afer Surgery (ERAS) en resecciones hepáticas abiertas por metástasis de origen colorrectal. Experiencia inicial. Rev argent cir [Internet]. 2016;108(1):1-10. Available from: http:// www.scielo.org.ar/scielo.php?script=sci_arttext \&pid=S2250639X2016000100002

13. McGlynn EA, Asch SM, Adams J, Keesey J, Hicks J, DeCristofaro A KE. The Quality of Health Care Delivered to Adults in the United States. N Engl J Med. 2003;348(26):2635-45.

14. Gustafsson UO, Hausel J, Thorell A L, O, Soop M NJ. Adherence to the Enhanced Recovery After Surgery Protocol and Outcomes After Colorectal Cancer Surgery. Arch Surg. 2011;146(5):571-7.

15. ERAS Compliance Group. The Impact of Enhanced Recovery Protocol Compliance on Elective Colorectal Cancer Resection. Ann Surg. 2015;261(6):1153-9.

16. Gillissen F, Hoff C, Maessen JM, Winkens B, Teeuwen JH, von Meyenfeldt MF et al. Structured Synchronous Implementation of an Enhanced Recovery Program in Elective Colonic Surgery in 33 Hospitals in The Netherlands. World J Surg. 2013;37(5):1082-93.

17. Levy BF, ScottMJ, FawcettWJ RT. 23-Hour-stay laparoscopic colec- tomy. Dis Colon Rectum. 2009;52(7):1239-43.

18. Gustafsson UO, Oppelstrup H TA, Nygren J LO. Adherence to the ERAS-protocol is associated with 5-year survival after colorectal cancer surgery: a retrospective cohort study. World J Surg. 2016;40(7):1741-7.

19. Delaney CP, Fazio VW, Senagore AJ R, B, Halverson AL RF. Fast track postoperative management protocol for patients with high co-morbidity undergoing complex abdominal and pelvic colorectal surgery. Br J Surg. 2001;88(11):1533-8.

20. Greco M, Capretti G, Beretta L GM, Pecorelli N B. Enhanced recovery program in colorectal surgery: ameta-analysis of randomized controlled trials. World J Surg. 2014;38(6):1531-41.

21. Nelson G, Kiyang LN, Crumley ET, Chuck A, Nguyen T, Faris P, et al. Implementation of Enhanced Recovery After Surgery (ERAS) Across a Provincial Healthcare System: The ERAS Alberta Colorectal Surgery Experience. World J Surg. 2016;40(5):1092-103.

22. Varadhan KK, Neal KR, Dejong CHC, Fearon KCH, Ljungqvist O, Lobo DN. The enhanced recovery after surgery ( ERAS ) pathway for patients undergoing major elective open colorectal surgery : A meta-analysis of randomized controlled trials q. Clin Nutr. 2010;29(4):434-40. Available from: http://dx.doi.org/10.1016/j. clnu.2010.01.004

23. Madani A, Fiore JF Jr, Wang Y, Bejjani J, Sivakumaran L, Mata J et. al. An enhanced recovery pathway reduces duration of stay and complications after open pulmonary lobectomy. Surgery. 2015;158(4):899-908.

24. Jeong O, Ryu SY PY. Postoperative Functional Recovery After Gastrectomy in Patients Undergoing Enhanced Recovery After Surgery: A Prospective Assessment Using Standard Discharge Criteria. Med Balt. 2016;95(14):e3140.

25. SongW, Wang K, Zhang RJ, Dai QX ZS. The Enhanced Recovery After Surgery (ERAS) program in liver surgery: ameta-analysis of randomized controlled trials. Springerplus. 2016;5:207.

26. Stowers MD, Manuopangai L, Hill AG GJ, Coleman B MJ. Enhanced Recovery After Surgery in elective hip and knee arthroplasty reduces length of hospital stay. Anz J Surg. 2016;86(6):475-9.

27. Xu W, Daneshmand S, Bazargani ST, Cai J, Miranda G, Schuckman $\mathrm{AK} E$ et al. Postoperative pain management after radical cystectomy: comparing traditional versus enhanced recovery protocol pathway. J Urol. 2015;194(5):1209-13.

28. Nelson G, Kalogera E DS. Enhanced recovery pathways in gynecologic oncology. Gynecol Oncol. 2014;135(3):586-94.

29. Mendivelso Duarte F, Barrios Parra AJ, Zárate-López E, NavasCamacho ÁM, Álvarez AO, Mc Loughlin S y cols. Asociación entre desenlaces clínicos y cumplimiento del protocolo de recuperación mejorada después de la cirugía (ERAS) en procedimientos colorrectales: estudio multicéntrico. Rev Colomb Cirugía. 2020;35(4):601-13.

30. Mc Loughlin S, Álvarez A, Falcão L, Ljungqvist O. The history of eras (Enhanced recovery after surgery) society and its development in Latin America. Rev Col Bras Cir. 2020;47(1):1-8. 